\title{
集合住宅における個別対応供給に関する研究 \\ A STUDY ON THE SYSTEM RESPONDING TO INDIVIDUAL USER NEED IN SUPPLYING OF CONDOMINIUM UNITS
}

\author{
野崎 薫 \\ Kaoru NOZAKI
}

\begin{abstract}
The purpose of this study is to discover how to properly respond to individual user needs for condominium units, which would also fall within suitable production costs. This study investigates user needs of three co-operative housing projects, three "I•SELCO System" condominiums and one high priced condominium. It is found that the more responding level is rose than satisfaction with persons in charge is down. And the user needs for the supply system about plan and closet has increased according to the size of housing unit and the experience about individual responding.
\end{abstract}

Keywords ;Housing System, Housing Needs, Apartment House, 住宅供給, 住要求, 集合住宅,

\section{1. 研究の背景と目的}

(1) 研究の背景

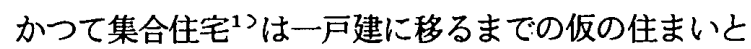

してとらえられることが多かったが、総務庁の平成五年 住宅統計調査（速報）による亡、共同住宅 $2>$ が占める割 合は、全国平均で $34 \%$ 、大都市圈 3 では $52 \%$ と既に 過半数を超えるにいたっている。もはや集合住宅は，都 市部における中心的な住戸形態として位置付けるべきで あろう。一方、戦後、住宅不足を解決するために、量的 供給を目指してきた流机から、集合住宅では不特定多数 を想定した企画型の供給が今だ主流である。しかし、昭 和 43 年には住宅総数が世帯総数を上回り、住宅問題は 量的充足から質の向上へと転換したと言わ机ている。そ れにともない「型」の概念による対応においては、昭和 50 年代後半に、「画一化」の問題か顕在化してきた。 昭和 60 年代には「多样化への対応」が重視されるよう になり、細かくライフスタイルを想定したプランニング がなされた。しかし、表層的なレベルでの「多様化への
対応」は、結果的には生活を規制し、かえって実生活と のミスマッチを生ぜしめた。その後バブル経済の崩壊と 共に、市場は急速に冷え込み、再び一次取得者向けの価 格を押えた画一的なプランニングが、新たに供給される 集合住宅の大半を占めるにいたっている。「多様化への 対応」は、必ずしも住まい手の個別的な生活にふさわし いものであるとは限らず、むしろ住まい手それぞれの個 別的な要望への対応を意図した「個別性への対応（以下 個別対応と略)小が、集合住宅においてもなされるべきで あると考えられる。

住まい手への個別対応ということでは、コーポラティ ブハウスにはすでに 20 年以上の実績がある。しかし、 1993 年末までの累積で 285 プロジェクト、584 9戸と、いまだ供給量は限られている。住まい手への個 別対応か、設計や施工への負担を増大し、そのことが結 果的に事業化の可能性を阻んでいるという状況がある。 コーポラティブハウスに限らず、広く集合住宅における 個別対応の普及を目指すならば、事業化を前提とし、企 
画・設計・施工を一体としてとらえた供給システムを 開発しなけ机ばならない。また集合住宅の場合、構造 的な問題から、戸建住宅と比較すると、個別対応の自 由度はおのずと制限される。そこで限定された対応で ありながらも、住まい手の要望をできるだけ満たすこ とのできる効果的な対応の在り方を検討する必要があ る。

集合住宅における工業化製品比率の向上については、 昭和 40 年代に画一的な大量生産方式の開発が進めら れたが、その後の多様化に対応できず衰退していった。 さらに昭和 50 年代には、公団において順応型住宅 ${ }^{45}$ ’やKE P(')ヤリープラン方式など、個別対応方式が 開発されたか、結果的には普及しなかった。個別対応 方式が普及しなかった要因の一つとして、集合住宅の 供給体制がプレハブ住宅の場合とは異なり、開発主体 之設計・施工の主体が異なり、個別対応のための設計 ・施工・部品・部材・情報システムを含めたトータル な開発がなされにくいことにあると考えられる。

さらに長い時間軸においては、日本の住まいは機能 的な面では確かに水潐は向上したが、この五十年間で 伝統的な住文化が失われ、質的な面では非常に貧困に なっている。数十年のローンと引換えに手に入れた住 まいであるにもかかわらず、自分や家族と共に生きて
いく唯一無二な特別の場所であるということが実感で きなくなっている。また住まい手の多くは、住まうこ とに対する自分なりの考えを見失い、商業主義にいた ずらに躍らされている。このような状況下において、 集合住宅において個別対応を行うことは、住まいに生 活を合わせるのではなく、生活に住まいを合わせるの だという認識を高め、ひいては住まい全般に対する意 識を高める可能性をはらんでいる。

\section{(2) 研究の目的}

集合住宅の住戸内部において、住まい手の個別的な 要望に的確に応え、なおかつ生産性ともバランスのと れた供給方式の在り様を検討することを究極的な目的 としている。需要者と供給者、住宅計画と住宅生産の 中間に立ち、供給システムを構筑していく上で要とな る事柄の構造を探り、さらに個別対応の普及度合と住 まい手の意識の変化に応じ、供給システムの更新の方 策についても検討する必要がある。そこで本論文では、 住まい手の侧の問題を中心とし、集合住宅におりる個 別対応供給に関する基礎的な知見を得ることを直接的 な目的としている。個別対応の程度の異なる複数の集 合住宅を調查対象とし、住まい手の供給方式に対する 評価特性を明らかにすると同時に、今後の供給方式に 関する意識の相違に着目し、供給方式の変化・発展の

表 1. 調查対象の概要

\begin{tabular}{|c|c|c|c|c|c|c|c|}
\hline & 宇渪 & 秋萁 & 由末 & 金文 & 柛戸 & 夕隆 & アクロ \\
\hline 所在地 & 八王子市久保山 & 八王子市別所 & 八王子市別所 & 檑捠市金欢区 & 神戸市中央区 & 大阪市天王寺区 & 荒川区南千住 \\
\hline 開発主体 & 公团 & 都公社 & 都公社 & 長谷工 & 長谷工 & 長谷工 & 辰谷工 \\
\hline 紛户数 & 76 户 & 115 戸 & 252 戸 & 394户 & 42 F & 87戸 & $682 \bar{F}$ \\
\hline 住戸面转 & 122 平米 & 104 平米 & 94 平米 & 93 平米 & 72 平米 & 76 平米 & 115 平米 \\
\hline 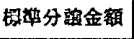 & 6035 万円 & 5190 万円 & 6983 万円 & 7413 万円 & 6121 万円 & 6977 万円 & 1 供 5 千万円 \\
\hline 率里工极金額 & 8 万円 & 123 万円 & 140 万円 & 82 万円 & 71 万円 & 68 万円 & 0 万円 \\
\hline 钤咕料 & 226 万円 & 36 万円 & 24 万月 & 0万円 & 0 万円 & 0 万円 & 0 万円 \\
\hline 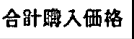 & 6269 万円 & 5348 万円 & 7147 万中 & 7495 万円 & 6192 万円 & 7045 万円 & 1 做 5 千万円 \\
\hline 瑊恷時期 & 89 年 5 月 & 88 年 11 月 & 91 年 3 月 & 93 年 $7 \cdot 9$ 月 & 93 年 $7 \cdot 9$ 月 & 93 年 $4 \cdot 6 \cdot 7$ 月 & 89 年 5 月 \\
\hline 入居時期 & 92 年 3月 & 90 年 5 月 & 93 年 3 月 & 94 年 3月 & 94 年 3 月 & 94 年3月 & 80 年 4 月 \\
\hline 闰查洔期 & 92 年 5 月 & 91 年 5 月 & 93 年 10 月 & 93 年 11 月 & 93 年 1 月 & 93 年 9 月 & $\begin{array}{l}90 \text { 年 } 1 \text { 亿月 } \\
9 \text { 年 } 2 \text { 月 }\end{array}$ \\
\hline 回叹数·率 & $62 \%(87 \%)$ & 95 ( $83 \%)$ & 115 㯖( $(66 \%)$ & 60 受( $(72 \%)$ & 28 票 $70 \%)$ & $69 \mathrm{~m}(71 \%)$ & 225 舜 $(43 \%)$ \\
\hline 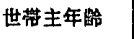 & 46 放 & 45 攱 & 44 诈 & 42 荿 & 41 偓 & 40 踄 & 46 敋 \\
\hline 家族人端 & 4. 1 人 & 3. 5 人 & 3. 7 人 & 3. 1 人 & 3. 2 人 & 3. 4 人 & 3. 2 人 \\
\hline 世荇年叹 & 1108 万円 & 826 万円 & 1089 万円 & 1179 万円 & 1185 万円 & 1283 万円 & 1548 万円 \\
\hline その他不動産 & $42 \%$ & $25 \%$ & $14 \%$ & $10 \%$ & $32 \%$ & $42 \%$ & $60 \%$ \\
\hline 間取り & 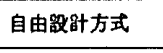 & 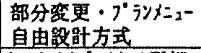 & ブラッッュー方式 & 固定方式 & 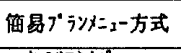 & 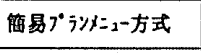 & 固定方式 \\
\hline 仕上げ & 完全け-ダ-方式 & 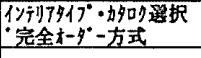 & 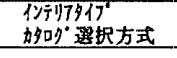 & 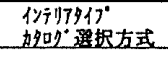 & 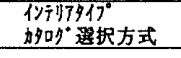 & 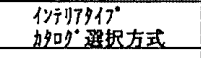 & 707-别汃-占式 \\
\hline 段借機器 & 自由垺倝方式 & 加哆選択方式 & 妙叭”選択方式 & $\pitchfork 7^{\circ} \%$ \%坊式 & 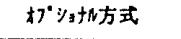 & 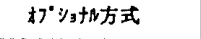 & 固定方式 \\
\hline 叹秋 & 自由t-タ+ -方式 & $\begin{array}{l}\text { 部分妶更 } \\
\text { 自由-早-万式 }\end{array}$ & 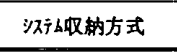 & $\star フ^{\circ} \% ョ+n$ 方式 & 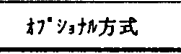 & 汉广人収納方式 & 固定方式 \\
\hline
\end{tabular}


方向を探る。

\section{(3) 関連する既往の研究}

住まい手への個別的な対応に関する研究としては、延 藤らによるコーポラティブ住宅の研究7)8 2 巽・高田ら による二段階供給方式の研究 ${ }^{9>10}$ がある。前者はコー ポラティブ住宅において「価値づくりの計画」がなされ ていることを仮説的に明らかにしているが、その実態は 住まい手と供給者の密度の高い人格的コミュニケーショ ンと相互作用を前提としており、量的供給は意図されて いない。後者は 1975 年以来、新しい都市住宅供給シ ステムとして研究開発を進め、大阪府住宅供給公社の亥 の子谷のプロジェクトで実際に二段階供給方式を適用し、 住まい手の評価特性と適応の意義について考察している。 基本的に本研究は後者の研究の流れに位置するが、さら にそれを発展させて、量的供給を前提とし、民間による 事業化が可能な供給システムの構築を意図している点に 特徵がある。

\section{2. 調查の概要}

\section{(1) 調査対象の概要}

経験した供給方式による意識の違いを分析するために、 表 1 にある 7 事例を調查対象として選定した。大別する
と3つのグループに分かれ、まず第一のグループはコー ポラティブハウスの 3 事例「グリーンヴィレッジ宇津木 (以下<宇津 >と略)」と「ベルデ秋葉台(以下<秋葉 $>$ と 略)」と「ノナ由木坂(以下<由木>と略)」で、これら はいずれも多摩二ュータウン内に位置し、供給主体は公 的な機関（住宅・都市整備公団と東京都住宅供給公社） による。<宇津〉は中央部分が配管スペースのトレンチ ゾーンに指定されている以外にはほとんど規制条件はな く、開口部の位置や外壁の形状屯含めて自由に設計する ことが可能。一方く由木>は総戸数が 252 戸と大規模 であることから、徹底したメ二ュー方式が採用されてい る。<秋葉>はこの 2 つ事例の中間に位置し、すへて 標準の標準設計、メ二ューの中から選択する希望設計、 部分的な変更もしくは自由設計による特別希望設計のい ずれかを選ぶことができた。このように同じコーポラテ ィブハウスでも対応のレベルの異なる事例を選定し、供 給方式による評価や意識の違いを比較検討している。

第2のグループは民間の H社が開発した「アイ・セル コ(造語・Interior Self Coordinate Systemの略)」を 採用した「マリンシティ金沢文庫(以下＜金文＞と略）」 と「グランフェルティ夕陽カ丘(以下<陽 $>$ と略 $) 」 と$

表 2. 住意識設問回答結果

25 歲以上の回答結果 (単位：\%)

\begin{tabular}{|c|c|c|c|c|c|c|c|c|}
\hline & $\begin{array}{c}\text { 宇禑 } \\
N=114\end{array}$ & $\begin{array}{l}\text { 秋蒠 } \\
N=94\end{array}$ & $\begin{array}{l}\text { 長池 } \\
N=127\end{array}$ & $\begin{array}{c}\text { 由木 } \\
N=201\end{array}$ & 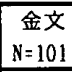 & 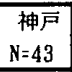 & $\begin{array}{r}\text { 輼 } \\
N=115\end{array}$ & $\begin{array}{l}\text { アクロ } \\
\mathrm{N}=222\end{array}$ \\
\hline 1.多少速くなっても、空気がきれいて健康的なところに住みたい & 76.5 & 77.7 & 81.5 & 75.6 & 76.2 & 58.1 & 48.7 & \\
\hline 2.多少家加くても、どこにでかけるにす便利な都心に住みたい & 24.4 & 21.3 & 32.2 & 27.9 & 32.7 & 62.8 & 69.6 & \\
\hline 3.家を選ぶなら、一般的に良いイメージの地域や沿線にこだわりたい & 73.9 & 72.3 & 79.6 & 75.6 & 79.2 & 86.0 & 91.3 & \\
\hline 4.多少交通の便が悪くなっても、一戸建の家に住みたい & 17.6 & 17.0 & 31.1 & 15.4 & 15.8 & 30.2 & 18.3 & \\
\hline 5. 余分にお金を払っても、なるへく眺めのよい高層階に住みたい & 31.9 & 30.9 & 36.7 & 38.3 & 34.7 & 34.9 & 53.0 & 51.8 \\
\hline 6. 1 軒の家にこだわらす、自分や家族の生活にあわせてその都度住み替え & 60.5 & 51.1 & 58.7 & 58.2 & 68.3 & 55.8 & 74.8 & \\
\hline 7.多少無理をしても将来のことを考えて、財産価值のある家に住みたい & 63.0 & 56.4 & 70.8 & 66.2 & 77.2 & 67.4 & 71.3 & \\
\hline 8. 自分にとって住みやすい家であれは、それを所有することにはこだわらない & 44.5 & 38.3 & 37.0 & 32.8 & 44.6 & 60.5 & 54.8 & \\
\hline 9.多少無理をしてす、それなりのステイタス・格式の咸しられる家に住みたい & 41.2 & 40.4 & 49.3 & 51.7 & 48.5 & 53.5 & 59.1 & \\
\hline 10.住みよい住まいなら、見栄にはこだわらない & 69.7 & 62.8 & 69.7 & 67.7 & 67.3 & 58.1 & 55.7 & \\
\hline 11. 住みよい住㻴境をつくるために、槙極的なコミュニ & 72.3 & 63.8 & 57.1 & 67.7 & 52.5 & 51.2 & 41.7 & 5 \\
\hline 12. 美しい街並をつくるために、布団や洗 & 45.4 & 55.3 & 45.0 & 42.3 & 59.4 & 74.4 & 75.7 & 2 \\
\hline 13.広い部屋をつくるためには、部屋数が少なくなっても仕方がない & 65.5 & 56.4 & 58.7 & 48.8 & 63.4 & 67.4 & 67.0 & \\
\hline 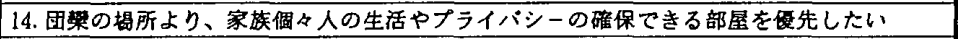 & 20.2 & 27.7 & 22.3 & 25.4 & 40.0 & 39.5 & 37.4 & \\
\hline 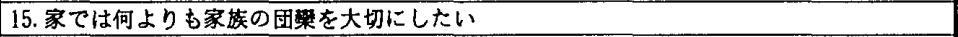 & 91.6 & 86.2 & 93.0 & 91.5 & 89.1 & 93.0 & 93.0 & $\overline{89.2}$ \\
\hline 16.家で過ごす時間はできるだけ增やしたい & 87.4 & 78.7 & 85.0 & 81.6 & 81.2 & 74.4 & 79.1 & 83 \\
\hline 17.1 & 59.7 & 0 & & 57.7 & 76 & & 67.8 & \\
\hline 18. 使いやすい & 43.7 & 39.4 & 41.0 & 36.8 & 37.6 & 27.9 & 35.7 & \\
\hline 19. 部屋の中に自分の気に入らないデザインや色の物は圈かない上うにしている & 64.7 & 63.8 & 61.9 & 68.2 & 68.3 & 76.7 & 79.1 & \\
\hline 20. 余分にお金を执っても、押しきせではい自分だけの間取り、インテリアにしたい & 64.7 & 58.5 & 57.1 & 54.2 & 52.5 & 48.8 & 67.0 & 66. \\
\hline 21.余分にお金を厸っても、生活の曼化に合わせて間取りを自由に変えていきたい & 67.2 & 66.0 & 68.9 & 63.2 & 65.3 & 51.2 & 66.1 & 69. \\
\hline 22. 余分にお。金を払っても、家むなとの時間が短䑿てきるサービスや機器があれば利 & 46.2 & 58.5 & 59.5 & 51.7 & 56.4 & 65.1 & 67.0 & \\
\hline 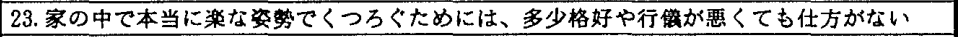 & 75.6 & 74.5 & 78.8 & 71.6 & 76.2 & 69.8 & 69.6 & \\
\hline 24.十分な駐車堨を備えるためには、遊び場や悢が少なくなっても仕方がない & 20.2 & 34.0 & 37.5 & 25.4 & 27.7 & 23.3 & 28.7 & \\
\hline 25. 余分にお枋金を払っても、共用施設や管理体制のしっかりした家に住みたい & 72.3 & 68.1 & 80.4 & 85.1 & 84.2 & 74.4 & 87.8 & \\
\hline 26.わざわざ尃用の客間をつくるよりは、居間を広くしてお客様もそこにとおすようにしたい & 89.1 & 87.2 & 89.5 & 93.0 & 90.1 & 88.4 & 88.7 & 89. \\
\hline 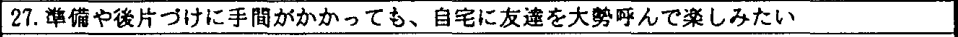 & 66.4 & 70.2 & 61.9 & 63.2 & 69.3 & 62.8 & 65.2 & \\
\hline 28. 洋間上り和室の方がくつろげる & 47.9 & 45.7 & 45.8 & 46.3 & 35.6 & 25.6 & 47.8 & \\
\hline
\end{tabular}

注・長池は由木の募莧段階の仮称、長池は募策段階、由木は入居後の回答結果 
方式が採用されている。

第3のグループに属するのは「アクロシティ(以下< アクロ〉と略)」で、開発主体は同じく H社である。奇 数階之偶数階でインテリアのカラータイプが異なる以外 は、通常の固定的な供給方式によって供給されている。 くアクロ>は分譲価格が 1 億円を超える所謂「億ション」 であり、住戸面積も比較的広く、日照・防音・使い勝手 ・共用施設・管理体制等の諸条件むある程度以上の水準 に達している。基本的な性能はある程度満たされている が個別的な対応はなされていない住まい手の、今後の供 給方式に対する意識を探ることを意図して調査対象に選 定している。

\section{（2）調查方法}

入居後に調查を実施した、<宇津 $><$ 秋葉 $><$ 由木 $>$ くアクロ〉については、インタビュ一調查と住戸観察調 查を行った上で、アンケート調查を実施。なおく由木＞ については購入申込み段階から追跡調查しており、入居 前後での住意識の変化、個別対応の観察調查等も実施し

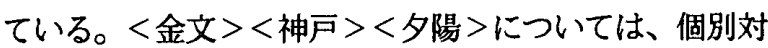
応終了後の購入者を対象にアンンケート調查を実施。さ らにくアクロ>以外の個別対応を実施しているすへて事 例について、その採用結果を分析すると共に、個別対応 担当者あるいは施工業者を対象にした定性調査も合わせ て行っているが、本報では住まい手を対象に実施したア ンケート調查の結果を中心に報告する。

\section{3．住まいに対する全般的な意識}

同居家族も含めて、28 項目の住意識設問への回答を 求め、2 5 歳以上の回答者について「そう思う」之答え た人の割合を表 2 に記載している。なおく由木>につい

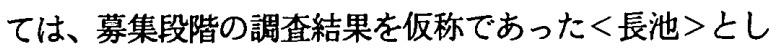
て加えている。そこで入居前後の意識の変化についてく 長池〉と<由木>の結果少ら分析すると、「一戸建」に 対するこだわりが $31 \%$ 加ら $15 \%$ へと半減しているー 方、「コミュニティ活動」や「遊び場や緑」に対する意 識が $10 \%$ 程度增しており、人居後少なからず集住意識 は高まっており、住民活動が活発なコーポラティブハウ スの特性が現われている。

立地に関しては、<宇津 $><$ 秋葉 $\rangle<$ 由木 $><$ 金文 $>$ に郊外志向、<神戸 $><$ 夕陽 $><$ アクロ $>$ に都市志向が 現われており、実際の立地条件を反映した結果となって いる。特にく陽 >くアクロ>は「住み替え」や「高層 居住」に対する意識が高く、都市居住に対する積極的な 態度がうかがえる。また郊外型のグループでは 全般的 に「コミュニティ活動」に対する意識が高いのに対して、
都心型のグループでは「街並」や「サービスや機器」に 対する意識が高くなっている。

「団樂」や「家で過ごす時間」に対する意識はいずれ の調查事例も高く、「居間を広くして接客もそこで」と 9 割前後の人が答えている。「お仕着せではない間取り やインテリア」や「間取りの変更」に対する意識は、く 神戸>がやや低いものの、その他の事例はいずれも5割 から 6 割が「そう思う」と答えている。住まいに対する 全般的な意識のレベルでは、個別的な対応についてはあ まり顕著な差は現れていない。一方、表には記載してい ないが、10 代後半を中心とする 25 歳未満の回答結果 では、「プライバシィが確保できる部屋」に対する意識 が高く、また「インテリア」や「デザイン」に対するこ だわりが強いという特徴が出ている。

\section{4、住まいに対する満足度}

間取り・仕上げ・設備機器・収納のそれそれについて 満足度を尋栘たところ (図 1 参照)、全般的に満足度が 高いのは間取りであり、満足度が低いのは収納であった。 まず間取りについては、<金文>で「まあ満足」が 6 割とやや多くなっていることと、<陽〉で「かなり満 足」と答えた人が一人もいないことを除けば、ほぼ同樣 な傾向を示している。ちなみに図で上位の事例ほど、個 別対応の自由度は高くなっている。特にコーポラティブ 八ウスの 3 事例については、自由設計方式からプランメ ニュー方式まで、個別対応の程度にかなり開きがあった にもかかわらず、満足度は極めて近倾している。仕上げ については、個別対応の自由度亡満足度が反比例してお り、最も自由度が高かったく宇津〉では、不満を感じて いるとする人が最も多く、評価が分散しており、個別対 応の自由度が增すことによって、かえって満足感が低下 している。設備機器についても、個別対応の自由度之渵 足度が反比例している。収納については、同じ事例でも 評価が分かれている点に特徽がある。特に<神戸 $>$ と< 夕陽 >の満足度が低くなっており、これは住戸面積が他 の事例と比較すると $20 \sim 50 \mathrm{~m}^{2}$ 近く狭く、収納スペ 一スの絶対量が不足していることによると思われる。

\section{5. 供給方式に対する評価}

\section{(1) 個別対応設計料に対する評価}

く宇津〉では設計料として、各戸工事金額に一律の係 数を掛けた金額が算出されており、平均設計料は 226 万円と他の事例と比較するとかなり高額である。これは 住戸内部の標準設計が一切なされておらず、全戸オリジ 
ナル設計であったことによる。く秋葉〉では、すへて標 準の標準設計であれば設計料は不要。希望設計・特別希 望設計では図面の枚数に応じて設計料が算出されており、 平均設計料は 36 万冈であった。由休〉では、<秋葉 $>$ の設計料の算出方法をより簡略化し、一律に、プラン メニューを選択すると 16 万円、部品・部材を選択すれ ば 16 万円、色を選択すれば 4 万円、以上すへてを選択 すれば最高で 40 万円の設計料が必要で、平均設計料は 24 万円であった。<金文 ><神戸 ><夕陽 >では、個 別対応については別途設計料は求めていない。

設計料については、7〜8割の人は高いと思っており、 「設計料を別途取らず、分譲価格の中に含んで欲しい」 と考えている人がかなりいた。金額の大小にかかわらず ローン対象外の支出が別途発生することは、経済的な面 のみならず、心理的な面でもかなり負担だったようであ る。またく由木>については、設計料の算出方法を合理 化した結果、一つだけの変更でも設計料を全額支払わね ばならず、そのことに対する不満意見もあった。このこ との背景には、たとえ一つの部品・部材の変更であって 屯、それに関連する図面はすへて修正しなければならい ということを多くの住まい手が必ずしも認識していない という実態か存在する。

別途支出が発生することに対する抵抗感はかなり強く、 「アイ・セルコ」の 3 事例では、開発主体が民間であり 販売率の低下を避けるため、標準分譲価格の中に含め金 額を明示していない。設計という作業に対するコスト意
識は、依然としてかなり低いが、将来的には設計に関わ る費用について、その根拠も含めて明確にし、応分の負 担への理解を高めていくことも、集合住宅の個別対応供 給における重要な課題の一つである。

\section{（2）変更工事金額に対する評価}

<宇津〉では、公団が予め戸当りの工事費用限度額を 指定しており、それを超えたのは 200 万円の住戸が 2 戸、110万円と 100 万円の住戸がそれぞれ 1 戸の計 4 戸のみで、平均すると変更工事金額は 8 万円と少ない。 く秋葉 >と<由木>では、標準仕様による標準分譲価格 との差額を変更工事金額として求めており、平均変更金 額は<秋葉>で 123 万円、<由木>で 140 万円だっ た。なお標準プランよりも部屋数の少ないプランメニュ 一を選択した場合、変更工事金額はその部分については マイナス計上される。<金文 $><$ 神戸 $><夕$ 陽 $>$ ではプ ランメニューとインテリアタイプの選択は無償で、部品 ・部材を変更した場合は標準仕様との差額が、新たに追 加した場合はその金額が加算される。平均変更工事金額 は<金文>が 82 万円、<神戸 >が 7 1万円、<夕陽> が68万円であった。いずれの事例においても変更工事 金額は平均分謞価格の $1 \sim 2 \%$ 程度であったにもかかわ らす、かなりの人が「高い」と感じていた。

\section{(3) 個別対応担当者に対する評価}

個別対応担当者に対する満足度を尋ねたところ、く宇 津>では「大変満足」が11\%、「ほぼ満足」が $26 \%$ で、合わせても $37 \%$ のしか満足と答えていないのに

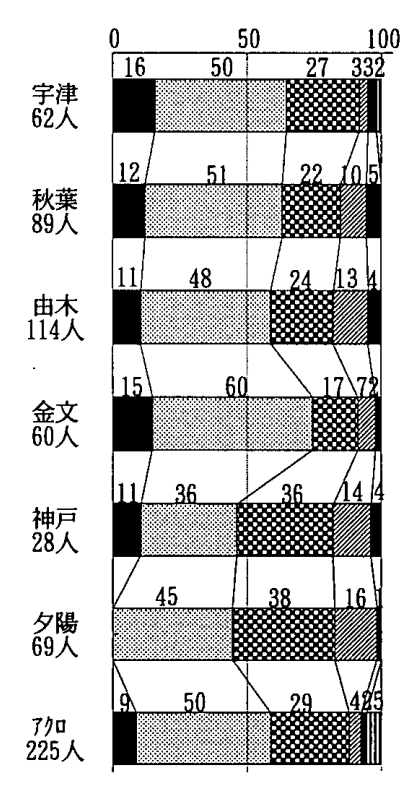

間取り

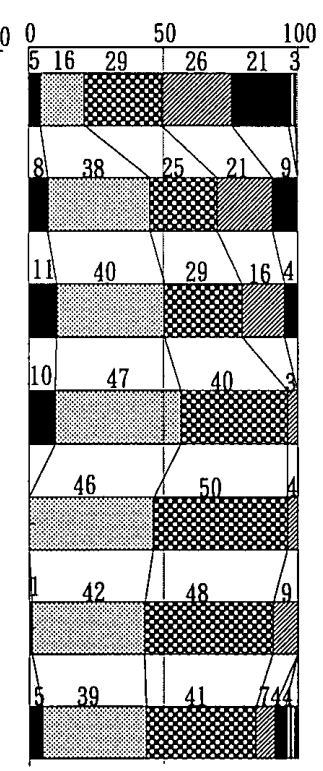

仕上げ

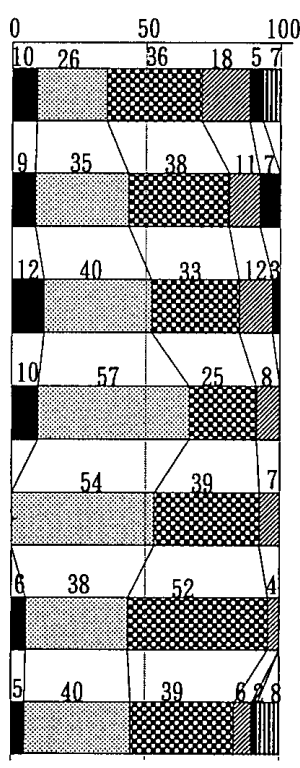

設備機器

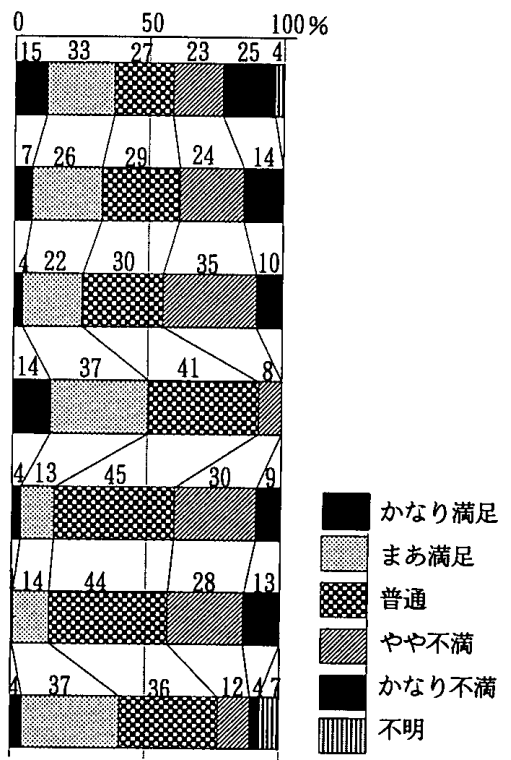

収納

図1．住まいに対する満足度 
対して、<由木>では $54 \%$ 、<金文>では $62 \%$ 、< 神戸>では $75 \%$ 、<夕陽>では $83 \%$ と、個別対応の 自由度が低ければ低いほど逆に満足度は高くなっている。 そこで個別対応の概要を整理する。＼cjkstart宇津〉では当初 1 回 2 時間半の計 5 回の対面設計に加えて、見積之図面 のチェックを数回予定していた。実際の対応は平均する 之、設計事務所あるいは自宅で 5.6 回、現場で 1.3 回、 電話・FAX等で 6.5 回、計 13.4 回の個別対応が行 なわれていた。しかし住戸によって打合せの回数にはか なりの開きがあり、2〜3回の打合せで終わった住戸も あれば、30回以上の住戸もあった。また、できないと 言われたことが入居後他の住戸で実現していることを知 り、新たな不満を抱いているケースもあった。このよう に対応に違いが出た要因の一つとして、個別対応を担当 した建築士 31 人が、それぞれ異なる設計事務所に属し ており、組織的な統一か弱かったことが関係していると 思わ机る。一方すへてメニュ一方式によるく由标〉では、 ほぼ当初の予定通り、平均 3.7 回、時間にして 4.9 時 間の打合せがなされていた。さらに住まい手はこれ以外 に、自宅やモテルルームで平均で 11.8 時間かけて検 討していた。しかし、3 時間未満の住戸が $24 \%$ 方、16 時間以上の住戸も $17 \% お り 、$ 住まいに対する こだわりの違いが時間の長短に現われている。く金文> の打合せの回数は 1.8 回の 52 分、<神戸>では 1.6 回の 57 分、<夕陽> 1.6 回の 60 分だった。これ以 外にそれぞれ事前に、2.5 時間、8.8時間、8.6 時 間かけて検討している。<由木>と比較すると同じメ ュ一方式でも選択肢が少なかったことから、相対的に時 間が短くなっている。また、く金文〉が 2.5 時間と特 に短いのは、モテルルーム・見本の展示・パンフレット ・積算ソフト等のプレゼンテーションッールが整備され ていたことが, 少なからず関係すると思われる。

一方、近年マーケティングの分野で着目されている顧 客満足度の概念は、完成した住望間についてのみならず、 個別対応のプロセスにおいても極めて重要な課題である。 個別対応すればするほど、個別対応担当者に対する評価 はそれとは反比例する形で下がっていることを充分留意 した上で、供給方式を検討しなければならない。いかに すれば個別対応の過程における満足度が高まり、かつ想 定した供給システムが有効に運営しうるかという観点か ら、モデルルーム・見本の展示・パンフレット・価格表 ・積算ソフト等のプレゼンテーションツールを開発する 必要がある。

\section{（4）選択肢に対する評価}

く宇津〉ではすへてて部品・部材を基本的には自由に選
ふことになっていたが、参考として用意された公団の標 準仕様のカ夕ログからすへて選択した住戸が、仕上げで $42 \%$ 、設備機器で $26 \%$ を占めた。極めて自由度の高 い供給方式であったにもかかわらず、限定された選択肢 の中から選んだ人がこれだけいたのは特筆すべき事実で ある。ちなみにく宇津〉では、間取り>収納 >価格調整 $>$ 設備機器 > 仕上げの順に、設計の際手間取った答えて おり、仕上げの優先順位が低かったことがうかがえる。 一方、く秋葉〉では、すへて標準のままの標準設計が

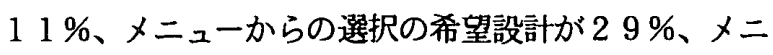
$z$ 一外の変更や部分的な変更を含む特別希望設計が 60 \%となっていた。また、部品・部材の種類数は標準仕样 で456 種類、メニューで401種類、さらに特別注文 が866 種類だった。フローリングや建具等の木質系材 料の色の選択結果を、主婦の年代別に見てみると、図 2 にあるように、30代と 40 代では中間色の茶色のミデ イアムオークを、20代と 50 代では濃いこげ茶色の夕 一クオークを選んでいるいる住戸が多くなっている。想

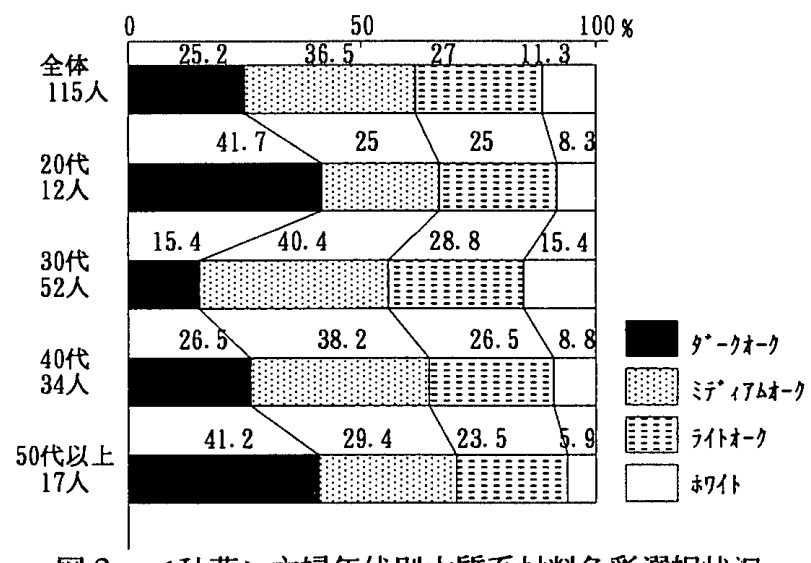

図 2.<秋葉>主婦年代別木質系材料色彩選択状況

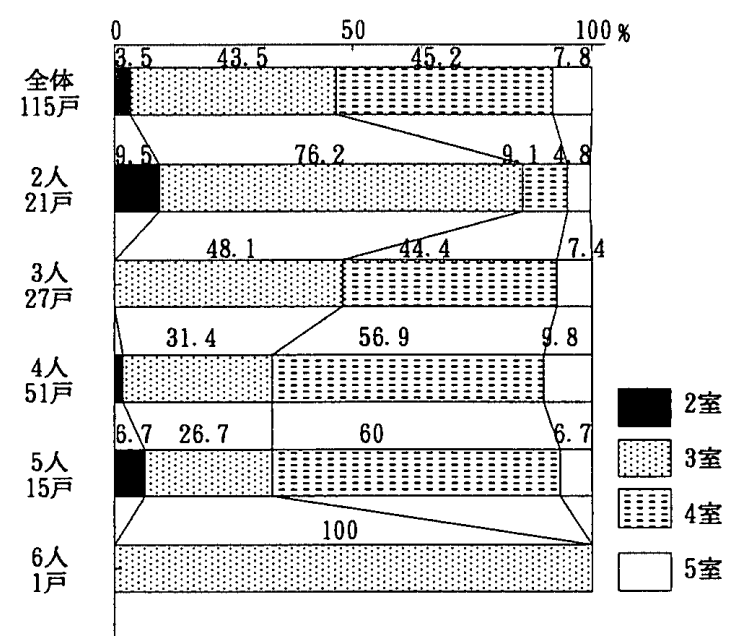

図 3. <秋葉>家族人数之居室数の相関 
定される入居者像を考慮して、ある程度選択肢の内容を 調整する必要がある。また家族人数別に、L D K 除く 他の居室の数を見てみると、図 3 にあるように 2 人家族 では 3 室が 8 割弱を占めているのに対して、3人家族で は 3 室と 4 室に分かれ、 4 人家族以上では 4 室が過半数 を占めている。家族人数に応じた居室数を供給するとい う点からも、個別対応供給は有効であると考えられる。 <秋葉〉では、仕上げ＞収納＞設備機器＞間取りの順に 手間取ったと答えており、く宇津〉とは間取りと仕上げ の順位が逆転している。

またく由木>では、色・部品・部材・間取りのすへて を選んだ住戸が最も多く $44 \%$ 、次いですへて標準の住

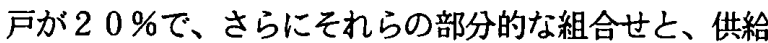
方式の選択結果も幅広く分散しており、住まいに対する こだわりの違いが出ていた。多様な対応の実現という点 からは、供給方式自体のフレキシビリティも重要であり、 同一プロジェクトにおいても供給方式を部分的に選択・ 組合せることができるよう検討する必要がある。一方、 プランメニューの採用結果は、図4にあるように、標準 設計の間取りを中心にかなりかたよった採用結果となっ ていた。台所がすへて独立型であったことから、対面力 ウンター方式などセミオープンなプランを用意するなど 改善の余地はあるものの、これ以上選択肢を增やす必要 は、現時点ではあまりないように思われる。
「アイ・セルコ」採用の 3 事例では、<金文>では、 インテリアタイプが 2 種類と他の事例と比較すると少な く、「もっとメニューの種類を增やしてほしい」と 30 \%が答えていた。 $82 \%$ 住戸が何らかの部品・部材を 選択しており、1戸当たりにすると平均 8 項目採用して おり、住戸面積が広ければ広いほど、世帯年収が高けれ ば高いほ亡゙、採用率は全般的に高くなっている。く神戸 >では、プランメニューが内容的に限定されていたこと から、わずか $18 \%$ の住戸でしか採用されていない。公 室ゾーンの床の標準仕様がじゅうたんであったことから、 フローリングへの変更が多く、その結果他の項目の採用 を压縮し、この事例でのみで採用された食器洗净機の採 用は $18 \%$ 8 にどまった。<陽>ではインテリアタイ プごとに部品・部材の選択肢が用意されており、異なる インテリアタイプのメニューからは選択できず、そのこ とに対して $33 \%$ の人が不都合を感じていた。選択肢を 追加もしくは充実してほしい項目は、食器洗浄機が3 5 \%、床暖房が $28 \%$ 、クローゼットが $26 \%$ だった。

\section{6. 今後の供給方式に対する意識}

間取り・仕上げ・設備機器・収納の 4 項目について、 今後の供給方式に対する意識について、それぞれ応分の 費用負担を想定した上で尋ねた。

（1）間取りに関する今後の供給方式

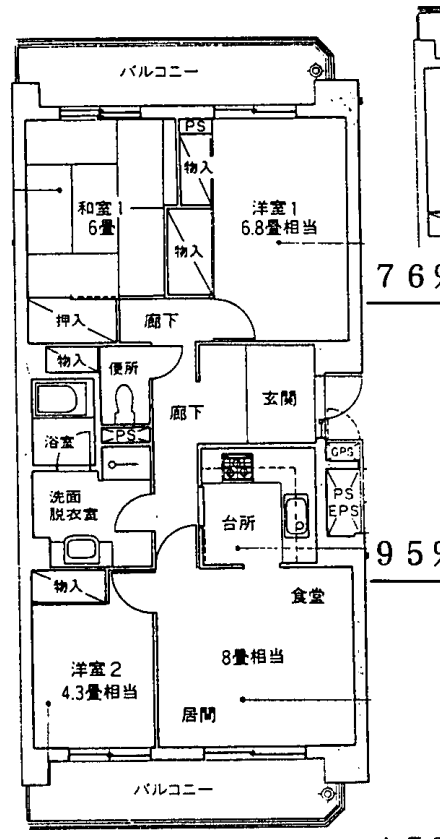

$45 \%$

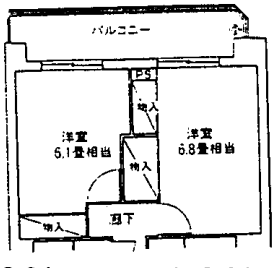

$12 \%$

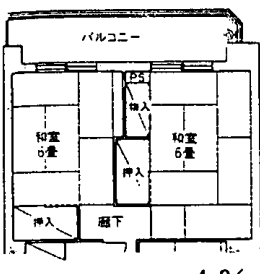

$4 \%$

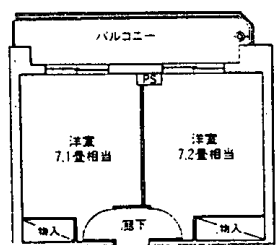

$4 \%$

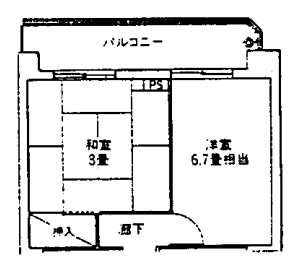

$4 \%$

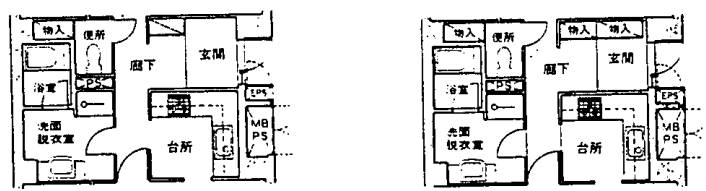

$0 \%$

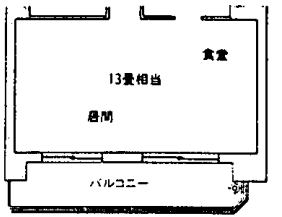

$16 \%$

$37 \%$

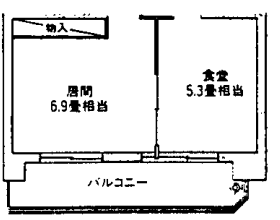

$2 \%$

図 4. く由木>プランメニュ一採用結果例 ( 3 L D K・ 77 平米・49戸) 
他の項目と比較して、最も顕著に調査対象による傾向 の違いが現われている（図 5参照）。自由設計方式だっ たく宇津〉では、今後の供給方式についてはプランメニ ュ一方式之自由設計方式に二分されているのに対して、 固定方式だったく金文〉では今後の供給方式についても 固定方式が多くなっている。くアクロ〉も固定方式だっ たが、く金文>と比較すると間取りの満足度がやや低く 世帯年収は倍と経斎的には恵まれていることからも、求 める対応の内容は高くなっている。

さらに住戸面積による意識の違いもあると思われるの で、面積的なバリエーションに富むく宇津〉を例に、図 9 より住戸面積別の意識の違いを分析する。小型住戸

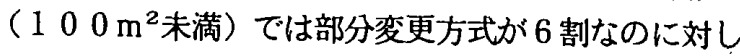
て、中型住戸 ( $100 \mathrm{~m}^{2}$ 以上 $130 \mathrm{~m}^{2}$ 末満) では自由 設計方式が $47 \%$ 、大型住戸 (1 $30 \mathrm{~m}^{2}$ 以上) では 5
$6 \%$ 之、求める個別対応のレベルは住戸面積に比例して 高くなっている。このことから間取りについては、経験 之面皘のそれぞれを軸に、求められる設計の自由度は今 後上昇していくもの之考えられる。

（2）仕上げに関する今後の供給方式

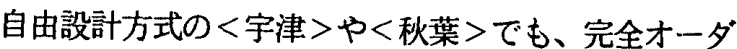
一方式を選んだ人はあまり多くない（図6参照）。仕上 げは住まい手がまず最初に興味を抱く項目ではあるが、 選ぶ楽しみから選ふ楛しみへの転換点が早く、自由設計 方式は将来的にもあまり求められない之思われる。全般 的な傾向としては、カ夕ログ選択方式を選んだ人が最む 多いものの、<金文〉や<神戸>では固定方式を選んだ 人が多くなっている。これは標準仕様のコーディネート の完成度に対して、カタログが内容的によ゙れを選んでも あまり変り映えせず、コーディネートしつうらかったこと
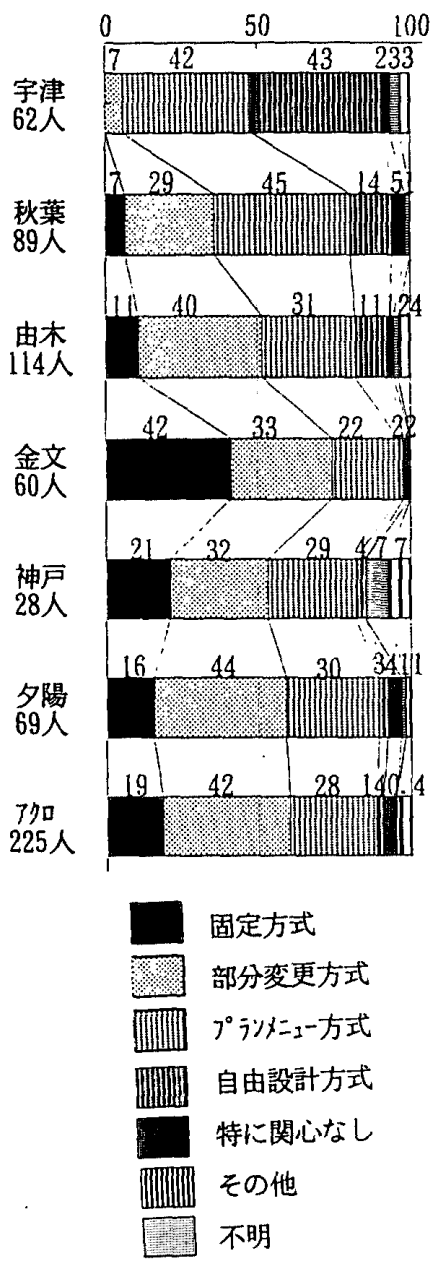

図 5。間取りに関する 今後の供給方式
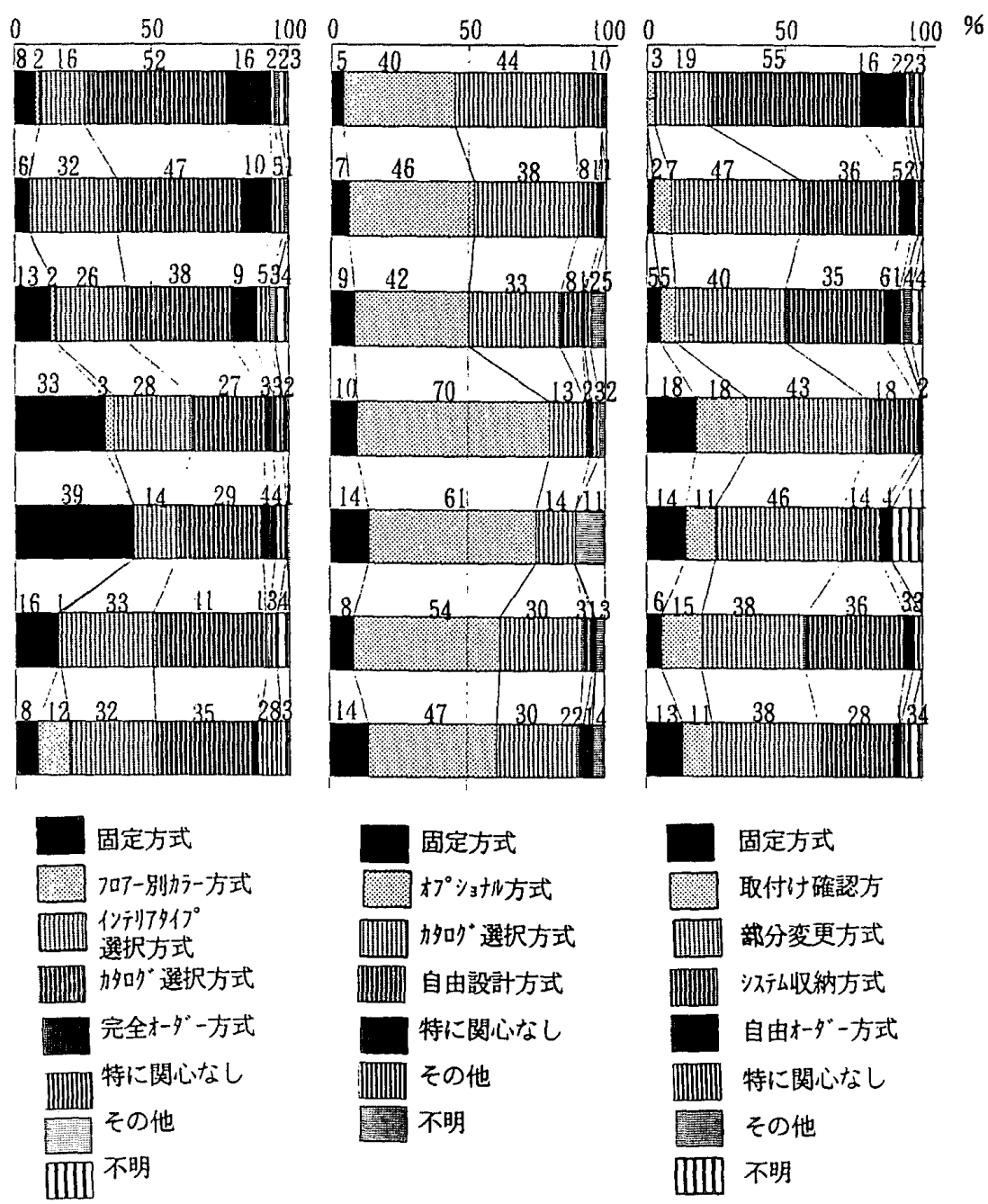

図6.仕上げに関する 今後の供給方式

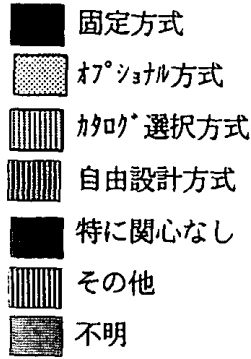

図 7．設備機器に関する 図 8．収納に関する 今後の供給方式

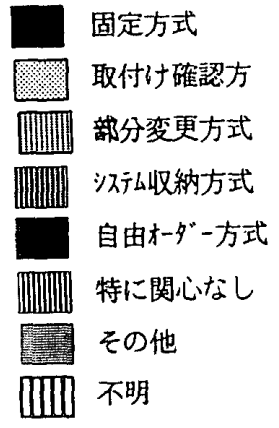

今後の供給方式 
などにもよると思われる。また図 10 にあるように住戸 面積による意識の違いはく宇津〉ではほとんど出ておら ず、むしろ仕上げに関する満足度との相関の方が強くな っている。

（3）設備機器に関する今後の供給方式

他の項目と比較すると、事例による意識の違いは最も 少ない（図 7参照）。全般的な傾向としては、オプショ ナル方式、次いでカ夕ログ選択方式を選んだ人が多くな っている。満足度が高い事例ほど、カ夕ログ選択方式よ りもより軽易なオプショナル方式を志向している点が着 目される。住戸面積による違いは、図 11 にあるように く宇津〉では、間取りや収納ほど顕著な違いは出ていな い。

\section{（4）収納に関する今後の供給方式}

収納に関しては満足度が低い事もあって、全般的に求 める対応のレベルは高くなっている（図 8参照）。また、 事例による意識の違い屯、間取り之並んでかなり明確に 出ている。全体的には部分変更方式もしくはシステム収 納方式を選んだ人が多くなっているが、自由設計方式で あったく宇津〉では、自由設計方式が $16 \%$ と他と比較 すると多くなっており、経験に応じて求める個別対応の レベルも高くなっている。また住戸面積による違いをく 宇津〉を例に分析すると、図 12 にあるように住戸面積 が広くな扎ばなるほど部分変更方式が減少して、自由オ 一ダー方式が増加している。このことから間取りと並ん で収納についても、経験と面積のそれぞれを軸に、求め られる個別的な対応の程度は今後上昇していくもの之考 えられる。

\section{7.まとめ}

\section{(1) 結果の要約}

本研究では、個別対応の程度が異なる複数の集合住宅 の住まい手を対象に、経験した供給方式に対する評価と 今後の供給方式に対する意識を探り、住まい手の側から 集合住宅における個別対応の在り方に関する基䃈的な知 見を得ようとした。その結果を要約すると以下のように なる。

(1)総体的に満足度が高いのは間取りについてであり、低 いのは収納についてである。仕上げと設備機器につい ては、個別対応の自由度が高ければ高いほよ゙、それに 反比例する形で満足度は下がっている。

(2)別途設計料や変更工事費用を支払うことについては、 額の多少にかかわらず現時点ではかなり抵抗感が強い。 (3)個別対応担当者への満足度は、設計の自由度が増せば 增すほど下がっており、さらに住戸による対応の相違 が新たな不満を誘発する原因になっている。

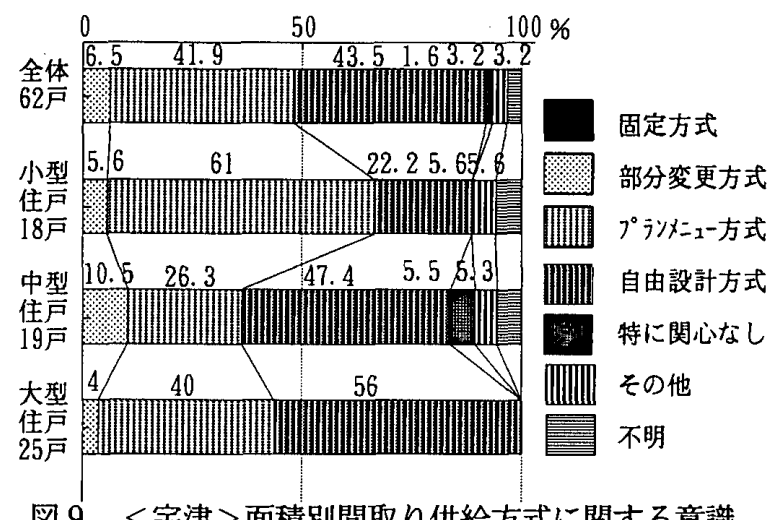

図 9，〈宇津>面積別間取り供給方式に関する意識

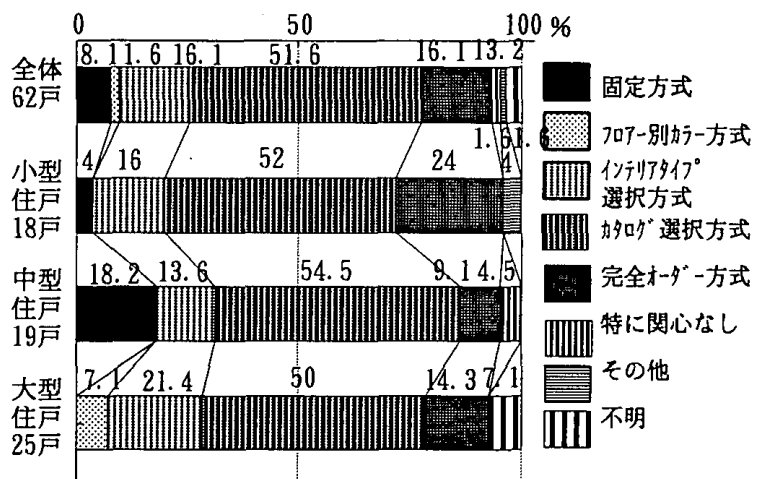

図 1 0. 〈宇津>面積別仕上げ供給方式に関する意識

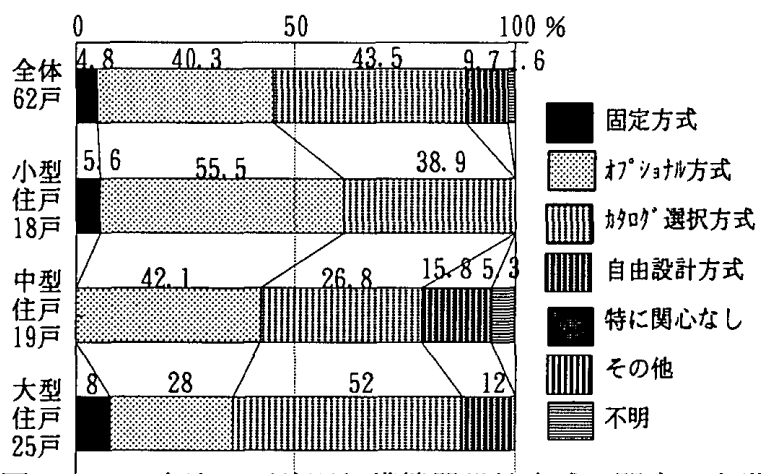

図 11 ．＜宇津＞面積別設備機器供給方式に関する意識

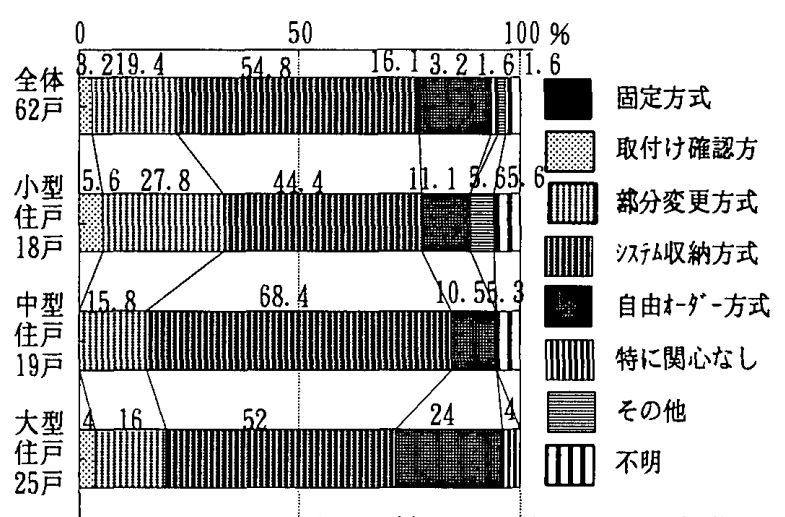

図 12．＜宇津>面積別収納供給方式に関する意識 
(4)間取り・仕上げ・設備機器・収納について、すへてを 変更、一部を変更、まったく変更しないなど、採用さ れた供給方式は同一調㚗対象においても、かなりのば らつきがあり、住まい手の住まいに対する意識の違い が現われている。

(5)今後の供給方式に対する意識は、間取りと収納につい ては経験と住戸面積に応じて求める個別対応の要望の 程度は高くなるが、仕上げや設備機器については標準 仕様の満足度の如何が、志向する供給方式を左右する 傾向が強い。

（2）集合住宅における個別対応の在り方に関する考察 人間の意識は、その時々の状況や経験に応じて常に変 化している。現時点では集合住宅は固定方式による供給 が一般的であり、個別対応はあくまでも例外的になされ ているに過ぎない。しかし、仮に今後集合住宅において も個別対応が普及したとするならば、住まい手の個別对 応に対する意識もしだいに変化する。一方、個別対応を 普及させていくためには、過剩な対応は費用対効果上避 ける必要があり、供給システムを検討するに当たっては、 その発展の枠組みをも含めて、住まい手の住意識、経済 力、個別対応の経験の程度、さらには住户面稘、基本設 計、標準仕様等に応じた対応をしていかなければならな い。

さらに個々の項目については、間取りと収納において、 住戸面積が広ければ広いほど、また個別対応を経験すれ ばするほど、求める対応の程度が向上している。間取り と収納については、間仕切りパネルやシステム収納の開 発など技術的な面での課題も含めて、今後集合住宅にお ける個別対応供給を検討する上で、中心的な課題として 位置付ける必要がある。仕上げと設備機器については、 個別対応の自由度が増せば増すほど䓟足度が下がってい ることから、いかに個々のプロジェクトに応じた適切な 選択肢を設定していくことができるかが課題となる。

\section{跔辞}

調查に御協力くださった、住まい手の皆榚、コープ住 宅推進協議会、住宅・都市整備公団、東京都住宅供給公 社の関係者の皆様に、感謝の意を表す。

なお、この論文は、1991 年から94 年にかけて日 本建築学会大会で発表したものをもとにまとめたもので ある。
<注。参考文献>

1)本研究では、笨合住宅を鉄骨鉄筋コンクリート造・铁筋コンク リート造・铁骨造の共同住宅と定義する。

2 )総務庁の住宅統計調查では、住宅を建て方別に、一戸建、長屋 建、共同住宅、その他に分類しており、本稿では共同住宅: =集 合住宅とする。

3)東京二十三区、横浜市、川踦市、千葉市の京浜、京葉を大都市 圈と定竘している。

4 )鈴木成文ほか：順応型住宅に関する調查研究報告费、財団法人 新住宅曾及会・住宅研究所報告曺、研究No. 7401、1974年9月、

5) 捨木成文ほか：順応型住宅に関する調查研究報告诸 I、盯団法 人新住宅普及会・住宅研究所報告書、研究No. 7401、1975年9月、

6)初見学ほか：KE P住宅における住まい方実態と可変性一住户 計画における個別対応に関する研究一その 1 一、昭和 58 年度日 本建築学関東支部研究報告费、第23、pp233 236、1983年、

7 )延藤安弘活 : コーポラティフ住宅の計画研究としての方法的 位置付けーユーコートの特質とその計画原理 (1)、日本:建築 学会計画系諭文報告集、第396号・pp. 12 19、1989年2月、

8 )延藤安弘活：価值つくりの計画としてみた個性的な住户平面 の評価ーユーコートの特澌とその計画原理（2）、日本建築学 会計画系論文報告集、第406号・pp. 87 99、1989年12月、

9 )巽和夫・高田光雄ほか：二段階供給方式に上る分謏集合住宅の 評価一その 1 -二段階供給方式方式対応住戸と一般住戸の比㣀 一、平成 2 年度日本建築学会近畿支部研究報告费、pp. $337 \sim 340$ 、 1990年、

10)巽和夫・高田光雄ほか：二段階供給方式による分譩策合住宅の 評価一その 2 ・段階供給方式方式とフリープラン售帒方式の 比較一、平成 2 年度日本建策学会近畿支部研究報告萣、pp. 341 ３44、1990年、

（1994年 8 月 8 日原稿受理，1995年 2 月 1 日探用決定） 